\title{
Pembinaan Tari di SLB Negeri Pembina Giwangan Yogyakarta
}

\author{
Daruni $^{1}$, Nurul Amalina ${ }^{2}$ \\ 1, 2 Jurusan Seni Tari, Fakultas Seni Pertunjukan \\ Institut Seni Indonesia Yogyakarta \\ Jalan Parangtritis Km 6,5, Sewon, Bantul, Daerah Istimewa Yogyakarta 55188 \\ No. Hp.: ${ }^{1}+62811267678,{ }^{2}+6285601529410$ \\ E-mail: 1daruni3@yahoo.com, nurulamalina447@gmail.com
}




\title{
Pembinaan Tari di SLB Negeri Pembina Giwangan Yogyakarta
}

\author{
Daruni ${ }^{1}$, Nurul Amalina ${ }^{2}$ \\ ${ }^{1,2}$ Jurusan Seni Tari, Fakultas Seni Pertunjukan \\ Institut Seni Indonesia Yogyakarta \\ Jalan Parangtritis Km 6,5, Sewon, Bantul, Daerah Istimewa Yogyakarta 55188 \\ No. Hp.: ${ }^{1}+62811267678,{ }^{2}+6285601529410$ \\ F-mail: 1daruni3@yahoo.com, 2nurulamalina447@gmail.com
}

\begin{abstract}
Abstrak
Sekolah Luar Biasa (SLB) Negeri Pembina Giwangan, Yogyakarta merupakan lembaga pendidikan yang menampung anak berkebutuhan khusus, dari tingkat SD hingga SMA, untuk memenuhi kebutuhan menyalurkan aneka talenta. Sekolah ini menyediakan fasilitas aneka kegiatan ekstrakurikuler, musik, gamelan, dan teater. Kegiatan seni yang belum berjalan dengan baik adalah kegiatan ekstrakurikuler tari. Oleh karena itu, kegiatan tari akan dilaksanakan untuk melengkapi kegiatan seni di SLB Negeri Pembina dengan cara melakukan pembinaan tari oleh dosen tari dari ISI Yogyakarta melalui LPM ISI Yogyakarta. Dalam melaksanakan kegiatan terdapat metode yang digunakan, yaitu metode imitasi dan analisis. Tahapan pelaksanaan diawali dengan perencanaan dilanjutkan pelaksanaan secara daring dengan mengirimkan video gerakan Tari Jabat Tangan. Hasil dari kegiatan adalah sebuah tarian pendek durasi lima menit berjudul Tari Jabat Tangan. Tarian tersebut diajarkan kepada para Pembina Tari SLB dan pengampu kegiatan ekstrakurikuler Tari.
\end{abstract}

Kata Kunci: pembinaan, tari, Sekolah Luar Biasa

\section{Dance Coaching in Pembina Giwangan Special State School}

\section{Abstract}

Pembina Giwangan State SLB (School for Disabled Children), Yogyakarta is an educational institution that accommodates children with special needs, from elementary to high school level, to meet the needs of channeling various talents. The school provides a variety of extracurricular activities: music, gamelan (Javanese instrument), and theatre. Among the arts extracurricular activities, dance is performing a bit lackluster. Therefore, ISI Yogyakarta dance major lecturers, through LPM ISI Yogyakarta, decided to coach the dance activity in Pembina Special School. The activity uses two methods: imitation and analysis. Implementation phase started with planning, followed with online practice by sending the Handshake Dance movement video in 5 minute duration. The dance is taught to the teachers and dance extracurricular coach in Pembina Special School.

Keywords: coaching, dance, School for Disabled Children 


\section{PENDAHULUAN}

Daerah Istimewa Yogyakarta dikenal sebagai kota pelajar. Berbagai sekolah dari tingkat SD, SMP, SMA, hingga perguruan tinggi tidak terhitung jumlahnya. Semua lembaga pendidikan berlangsung dan mampu memenuhi kebutuhan masyarakat. Kota Yogyakarta juga disebut sebagai miniatur Indonesia karena banyaknya pendatang dari seluruh penjuru Indonesia untuk melanjutkan pendidikan di Yogyakarta (Yu, 2019:2). Semua anggota masyarakat berhak mendapatkan pendidikan tidak terkecuali, termasuk penyandang difabilitas. Pemenuhan hak kaum difabel pada seluruh warga untuk memenuhi HAM merupakan salah satu upaya mencapai kemanusiaan yang adil dan beradab (Wajdu, 2019:2). Pemerintah menyediakan sekolah untuk mereka, salah satu sekolah "istimewa" tersebut adalah Sekolah Luar Biasa (SLB). Menurut Khikmawati (2020:2), SLB adalah sekolah bagi individu yang memiliki kesulitan dalam belajar dikarenakan gangguan mental, fisik, serta emosional.

Sekolah Luar Biasa (SLB) Negeri Pembina Giwangan, Yogyakarta memiliki guru berjumlah 65 orang yang bertanggung jawab mengajar anak didik berjumlah 238 siswa (139 siswa laki-laki dan 99 siswa perempuan). Aktivitas pembelajaran dilaksanakan lima hari kerja. Di samping mereka belajar sesuai dengan kurikulum, mereka juga diajarkan kegiatan yang bersifat menggali potensi talentanya, antara lain kegiatan aneka seni, seperti seni musik, teater, kuliner, dan olahraga. Pemerintah beberapa tahun lalu mencanangkan otonomi daerah, salah satunya dengan memberikan keluasan ruang gerak kepada SLB untuk mengelola sumber daya yang ada dengan cara mengalokasikan seluruh potensi dan sumber daya dengan sistem pembelajaran yang inovatif dan kreatif (Sukadari, 2020:4). Siswa dibagi dalam beberapa kelas sesuai kategori. Mereka mendapatkan materi sesuai minat bakat dalam satu semester. Setiap pertemuan pelatihan dilaksanakan 90 menit, dan diambil waktu istirahat 10 menit. Satu materi bervariasi penyelesaian pemberian materinya, ada yang sampai berapa kali pertemuan apabila panjang dan rumit. Ada pula yang singkat diberikan lima atau empat kali pertemuan. Beberapa kegiatan diikuti siswa dengan antusias, baik yang memilih bidang seni, kuliner, maupun olahraga.

Proses pembelajaran yang sudah dilaksanakan berjalan baik, tertib, lancar, tecermin ketika mereka memahami dan mengamalkan kedisiplinan dengan bukti hasil yang dicapai sesuai dengan kemampuan siswa yang mengalami tunagrahita, tunadaksa, dan autis. Mereka belajar seni musik, olahraga, dan kuliner melalui beberapa tahap, dari yang pola paling sederhana, dimainkan dan dilakukan sesuai materi ajar. Kemudian pada fase tertentu mereka menunjukkan keterampilan dengan keterampilan yang lebih sulit.

SLB Negeri Pembina Giwangan seringkali mengadakan acara yang sifatnya seremonial dan merayakan syukuran hari lahir sekolah. Tahun 2020, mereka merayakan dan memeriahkan acara ulang tahun sekolah dengan sebuah karya tari. Untuk mewujudkan keinginan tersebut, sekolah melayangkan surat kepada Lembaga Pengabdian ISI Yogyakarta meminta bantuan tenaga penyuluh tari. LPM merespons dengan cepat dan memberi solusi menjanjikan untuk mengirim dosen penyuluh tari.

SLB Negeri Pembina merupakan lembaga pendidikan yang menampung anak berkebutuhan khusus, dari tingkat SD hingga SMA. Untuk memenuhi kebutuhan menyalurkan aneka talenta, sekolah menyediakan fasilitas aneka kegiatan ekstrakurikuler, musik, gamelan, dan teater. Kegiatan seni yang belum berjalan dengan baik ialah kegiatan ekstrakurikuler tari. Oleh karena itu, kegiatan tari dilaksanakan untuk melengkapi kegiatan seni di SLB Negeri 
Pembina. Tujuan diadakan penyuluhan ini sebagai wujud pengabdian lembaga tinggi seni dengan ujung tombak para dosen untuk mengabdi kepada masyarakat sesuai dengan kebutuhan masyarakat. Singkat kata, perguruan tinggi seni membantu memenuhi kebutuhan masyarakat dalam hal ini SLB Negeri Pembina Giwangan, Yogyakarta.

\section{METODE PENGABDIAN}

a. Metode Perencanaan

Metode perencanaan yang dilakukan adalah melakukan perkenalan dengan lingkungan sekolah dan anak didik. Khalayak sasaran kegiatan perencanaan adalah SLB Negeri Pembina Giwangan Yogyakarta, dengan tempat kegiatan di SLB Negeri Pembina Giwangan Yogyakarta

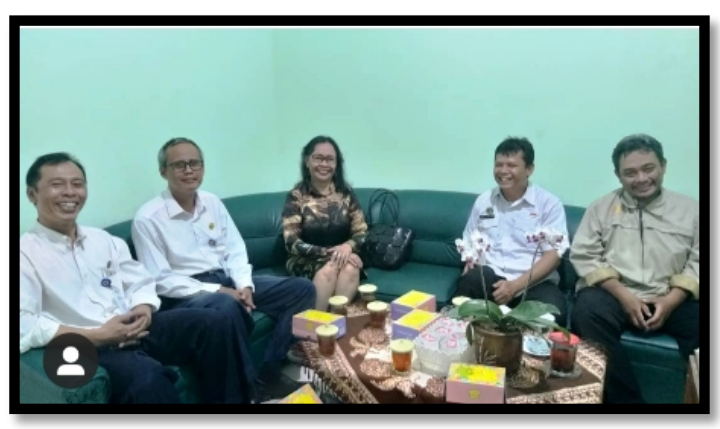

Gambar 1 Penerjunan Tenaga Penyuluh di Kelurahan Giwangan, Yogyakarta

b. Metode Pelaksanaan

Metode pelaksanaan yang digunakan dalam kegiatan pengabdian kepada masyarakat ini adalah sebagai berikut.

Tabel 1 Pelaksanaan Kegiatan

\begin{tabular}{|l|l|l|}
\hline $\begin{array}{l}\text { Pertemuan } \\
\text { ke- }\end{array}$ & Materi & Peserta \\
\hline 1 & $\begin{array}{l}\text { Perkenalan, berkeliling sekolah dengan } \\
\text { melihat aneka fasilitas dan aneka } \\
\text { ekstrakurikuler di SLB Negeri Pembina, } \\
\text { berjumpa dengan para siswa peserta } \\
\text { ekstrakurikuler Tari. }\end{array}$ & $\begin{array}{l}\text { semua peserta, } \\
\text { pembina, dan siswa }\end{array}$ \\
\hline 2 & $\begin{array}{l}\text { Mengumpulkan semua pembina } \\
\text { ekstrakurikuler untuk membahas materi yang } \\
\text { akan dipentaskan dalam lustrum sekolah, } \\
\text { sepakat akan "menjahit" aneka kegiatan dalam } \\
\text { satu paket pertunjukan yang meliputi unsur } \\
\text { tari, gamelan, band, dan teater. Tema tentang } \\
\text { persahabatan berteman tanpa batas. Tema ini } \\
\text { muncul karena teman disabel sering menjadi } \\
\text { "korban" diskriminasi dalam topik } \\
\text { pertemanan }\end{array}$ & $\begin{array}{l}\text { semua pembina } \\
\text { ekstrakurikuler }\end{array}$ \\
\hline 3 & $\begin{array}{l}\text { Mulai membuat jadwal kerja studio masing- } \\
\text { masing penanggung jawab kegiatan, } \\
\text { penugasan siapa membuat naskah, melatih } \\
\text { gamelan, melatih band, dan penanggung } \\
\text { jawab tari. Dibagi ada "flashmob", ada tari }\end{array}$ & $\begin{array}{l}\text { pembina } \\
\text { ekstrakurikuler, band, } \\
\text { tari, gamelan, dan } \\
\text { teater }\end{array}$ \\
\hline
\end{tabular}




\begin{tabular}{|c|c|c|}
\hline & $\begin{array}{l}\text { fable dengan aneka macam binatang dan } \\
\text { tumbuhan agar menarik secara visual. }\end{array}$ & \\
\hline $4-6$ & $\begin{array}{l}\text { Pemberian materi belajar bergerak, } \\
\text { menuntun para siswa dan mengobservasi } \\
\text { kemampuan daya imitasi, daya tangkap anak } \\
\text { berkebutuhan khusus, pemberian materi } \\
\text { menyesuaikan. }\end{array}$ & pembina tari dan siswa \\
\hline $7-12$ & $\begin{array}{l}\text { Mendadak mengubah peserta, para pembina } \\
\text { tari yang diajar melalui daring, memberikan } \\
\text { materi urutan gerakan, lokomotor, dan } \\
\text { stasioner } \\
\text { a. } \quad \text { gerak lembehan mengepalkan tangan ayun } \\
\text { hasta } 3 \text { kali } 8 \text { hitungan menuju ke titik } \\
\text { pusat menari. } \\
\text { b. } \text { stilisasi gerak berjabat tangan variasi kaki } \\
\text { gedrug kanan, gedrug kiri, tangan menjulur } \\
\text { berlawanan arah, dilakukan bergantian } \\
\text { dengan tepuk tangan ke samping atas, } \\
\text { berulang } 4 \text { kali. } \\
\text { c. kaki gedrug bergantian kanan kiri tangan } \\
\text { mengepal di samping ayun ke depan ke } \\
\text { belakang dalam } 4 \text { kali } 8 \text { hitungan. } \\
\text { d. kaki kuda-kuda kembar cindheg } 2 \text {, doble } \\
\text { step di tempat bergantian, tangan nulak } \\
\text { cangkeng ( methentheng) } \\
\text { e. tangan kakan nguping, kaki doble step ke } \\
\text { samping kanan dan kiri bergantian } 2 \text { kali } \\
8 \text { hitungan membalik } 180 \text { derajat } \\
\text { menghadap ke belakang. } \\
\text { f. kembali ke depan dengan cara yang } \\
\text { sama. } \\
\text { tangan nulak cangkeng, kaki kiri sarug } \\
\text { h. kaki adeg-adeg, tangan ngerumbai, seperti } \\
\text { tangan boneka angkrek. } \\
\text { mengulang dari seri A, B, A, B variasi } \\
\text { putar dan tangan sembah di dada }\end{array}$ & pembina tari \\
\hline
\end{tabular}

Materi penyuluhan ialah Tari Jabat Tangan. Metode yang digunakan adalah imitasi dan analisis. Pelaksanaan kegiatan penyuluhan tentu saja menghadapi kendala. Dalam melaksanakan penyuluhan setelah beberapa kali pertemuan pascapenerjunan, terjadi wabah penyakit yang berasal dari Wuhan yang disebut Covid-19. Dampaknya "menyedihkan" karena semua aktivitas manusia seluruh dunia terhenti. Beberapa negara "mengunci diri” dengan cara semua warga tidak diizinkan ke luar dan warga luar tidak diizinkan masuk. Hal itu berdampak pada semua warga negara mana pun termasuk kegiatan penuyuluhan ini. Kegiatan dalam pelatihan tari terhenti dan berpindah ke kegiatan daring, juga rencana untuk mengajar para siswa tidak dilaksanakan karena situasinya tidak memungkinkan. Target hasil pelatihan yang rencana akan dipentaskan pada bulan Juni tidak terlaksana, bahkan acara Lustrum SLB Negeri Pembina juga dibatalkan. 


\section{HASIL DAN PEMBAHASAN}

Hasil penyuluhan adalah sebuah tarian pendek durasi lima menit berjudul Tari Jabat kepada para pembina tari SLB dan pengampu kegiatan ekstrakurikuler tari.

Tangan. Harapannya tarian itu diajarkan

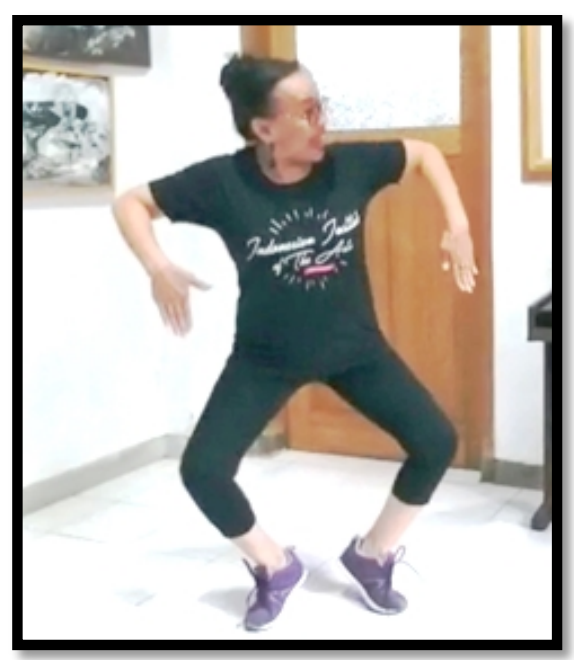

Gambar 2 Pelatihan Tari Secara Daring

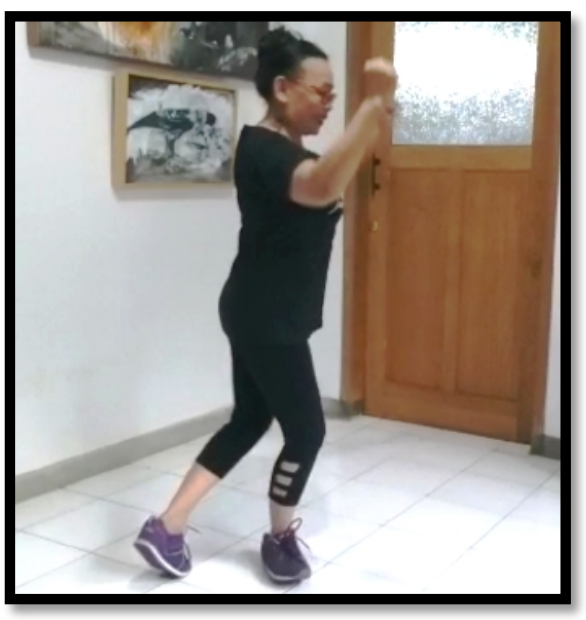

Gambar 3 Salah Satu Sikap Tari dalam Pelatihan Daring 


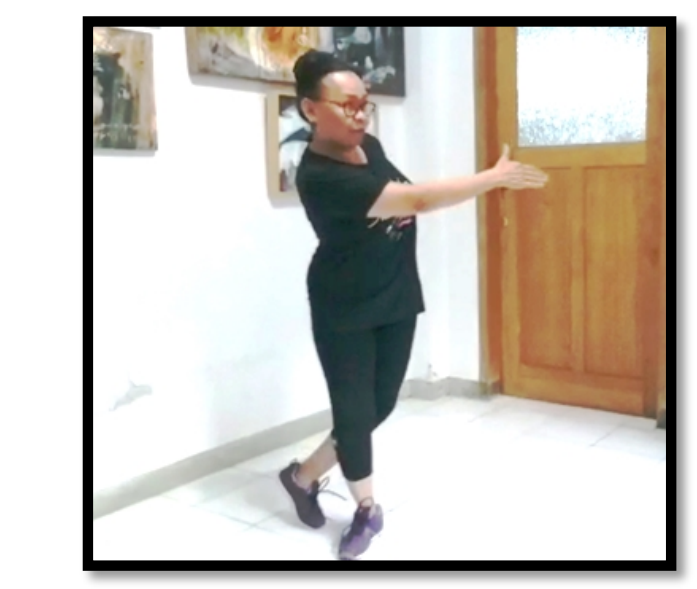

Gambar 4 Sikap Salah Satu Ragam dalam Pelatihan Daring

\section{SIMPULAN}

Bersyukur meskipun kegiatan ini mendapat kendala di luar kuasa manusia dikarenakan adanya Covid-19 tanpa didugaduga "menghancurkan" rencana penyuluhan, penyuluhan tetap dilaksanakan secara daring. Hasil penyuluhan yang rencananya dipentaskan untuk Lustrum Sekolah Luar Biasa Negeri Pembina, dosen penyuluh akhirnya harus melakukan gerak cepat menggeser target semula. Berbesar hati menerima setiap peristiwa, bahwa manusia tidak mempunyai kuasa apa-apa. Acara tetap berjalan dan tidak terhenti, tetapi target harus disesuaikan. Puji Tuhan meskipun pentas lustrum batal dilaksanakan, kegiatan tetap berjalan dengan cara daring melalui platform pengiriman video.

\section{SARAN}

Melihat rencana semula yang akhirnya bergeser dikarenakan kondisi pandemik ini, tentu saja ada rasa yang kurang karena pelaksanaan kurang maksimal. Untuk itu, besar harapan apabila pada kesempatan berikutnya SLB Negeri Pembina dan beberapa kesenian di Kelurahan Giwangan, Yogyakarta dapat diikutkan dalam Program Pembinaan Wilayah Seni.

\section{UCAPAN TERIMA KASIH}

Puji syukur ke hadirat Allah SWT atas rahmat-Nya, yang telah memberikan kekuatan kepada penulis dapat menyelesaikan artikel jurnal pengabdian keada masyarakat yang berjudul "Pembinaan Tari di SLB Negeri Pembina Giwangan, Yogyakarta”. Ucapan terima kasih penulis sampaikan kepada LPM ISI Yogyakarta dan semua pihak yang telah membantu memperlancar dalam pelaksanaan kegiatan hingga terselesaikannya jurnal ini.

\section{DAFTAR PUSTAKA}

Khikmawati, Devi Kurnia, Tina Indria Astuti, \& Any Novitasari. (2020). "Penerapan E-Learning pada Sekolah Luar Biasa”, Dialektika Jurnal Bahasa, Sastra, dan Pendidikan Bahasa dan Sastra Indonesia, Vol. 7 No. 1, Universitas Muhamadiyah Surakarta.

Sukadari. (2020). "Pembelajaran Tematik bagi Anak Berkebutuhan Khusus di Sekolah Luar Biasa Kelas Rendah”. G-Couns: Jurnal Bimbingan dan Konseling, Vol. 4 No. 2, Juni, Program Pascasarjana IKIP PGRI Yogyakarta.

Yu, Steffanie \& Ari Setyaningrum. (2019). "Studi Mengenai City Branding 
Kota Yogyakarta sebagai Kota Pelajar Indonesia”, Matrik: Jurnal Manajemen, Strategi Bisnis dan Kewirausahaan, Vol. 13 No. 1, Februari, Fakultas Ekonomi \& Bisnis, Universitas Katolik Atma Jaya Yogyakarta.
Wajdu, Fajar. (2019). "Pemenuhan Hak-Hak Kaum Difabel dalam Rangka Hak Asasi Manusia", Palita Journal of Social Region Research, Vol. 4 No. 2, Fakultas Syariah dan Hukum IAIN Bone. 